\title{
Effect of immobilized fungal phytase on growth performance and bone traits of broilers fed with low dietary calcium and phosphorus
}

\author{
Sreeja Ajith ${ }^{1,2}$, Divya Shet ${ }^{1,3}$, Jyotirmoy Ghosh ${ }^{1}$, Vaibhav B. Awachat ${ }^{1}$, Karthik Bhat ${ }^{1}$, Dintaran Pal ${ }^{1}$ and \\ Arumbackam V. Elangovan ${ }^{1}$
}

1. ICAR-National Institute of Animal Nutrition and Physiology, Bengaluru, Karnataka, India; 2. Department of Microbiology, Jain University Bengaluru, Karnataka, India; 3. Department of Biotechnology, Jain University, Bengaluru, Karnataka, India.

Corresponding author: Arumbackam V. Elangovan, e-mail: avelango@yahoo.co.in Co-authors: SA: sreejabpillai@gmail.com, DS: shetdiv@gmail.com,

JG: jghosh68@gmail.com,VBA: vaibhav.cari@gmail.com,KB: karthik_4596@yahoo.co.in, DP: dtpal@yahoo.co.in Received: 05-02-2018, Accepted: 30-04-2018, Published online: 07-06-2018

doi: 10.14202/vetworld.2018.758-764 How to cite this article: Ajith S, Shet D, Ghosh J, Awachat VB, Bhat K, Pal D, Elangovan AV (2018) Effect of immobilized fungal phytase on growth performance and bone traits of broilers fed with low dietary calcium and phosphorus, Veterinary World, 11(6): 758-764.

\begin{abstract}
Aim: The aim of this study was to investigate the effects of phytase which was laboratory produced by Aspergillus foetidus on the growth performance, mineral retention, and bone traits of broilers fed with low dietary calcium and phosphorus.

Materials and Methods: The extracellular phytase enzyme secreted into the crude filtrate was concentrated by ammonium sulfate precipitation to obtain an activity of 500 phytase units (FTU). A total of 90 1-day-old chicks (Cobb 500) were randomly divided into three treatment groups with five replicates having six birds each. Dietary treatment, T1, was with $0.45 \%$ non-phytate $\mathrm{P}$ (NPP) during starter and $0.40 \%$ during finisher phase with $1 \% \mathrm{Ca}$. Dietary treatment, $\mathrm{T} 2$, had $0.37 \%$ NPP during starter and $0.32 \%$ in finisher phase with $1 \% \mathrm{Ca}$ and supplemental lab phytase at $500 \mathrm{FTU} / \mathrm{kg}$. Dietary treatment, T3, was similar to T2 with a lower Ca of $0.8 \%$.
\end{abstract}

Results: There was no significant difference among the dietary treatments with regard to body weight gain, feed intake, feed conversion ratio, and $\mathrm{Ca}$ retention ( $\mathrm{p}>0.05$ ). However, a significant improvement in retention of $\mathrm{P}$ by birds was observed in phytase supplemental groups T2 and T3 $(\mathrm{p}<0.05)$. Dry weight of tibia $(2.58-2.78 \mathrm{~g} / \mathrm{kg}$ live weight) and ash content (39.741.8\%) was comparable among treatments. A similar trend was observed for bone $\mathrm{Ca}, \mathrm{P}$, and Mn content.

Conclusion: The study indicated that $500 \mathrm{FTU} / \mathrm{kg}$ phytase can be effectively supplemented in a broiler diet with low phosphorus $(0.37 \%$ in starter and $0.32 \%$ NPP in finisher diet) and low calcium $(0.8 \%$ in diet) for better growth performance and with successful replacement of dietary $\mathrm{P}$ by $0.08 \%$ and reduced $\mathrm{P}$ excretion into the environment in broiler chicken.

Keywords: broiler, calcium, phosphorus, phytase.

\section{Introduction}

Phytase is a phosphomonoesterase capable of hydrolyzing phytate (inositol hexaphosphate IP6) to inorganic phosphate and other minerals that are readily absorbed by the monogastric animals [1]. Phytase is globally accepted as feed enzyme for monogastric animals and has been a crucial area for poultry and pig research. The upshot of phytase over $\mathrm{P}$ availability and its advantages are well established which enlightens on improved weight gain, mineral retention, metabolizable energy, and amino acid digestibility in poultry [2-5]. Positive effects of microbial phytase were reported on the digestibility of $\mathrm{Ca}, \mathrm{Mg}$, $\mathrm{Na}$, and $\mathrm{K}[6,7]$. The bioavailability of $\mathrm{P}$ and other minerals such as $\mathrm{Ca}, \mathrm{Cu}$, and $\mathrm{Zn}$ due to the addition

Copyright: Ajith, et al. Open Access. This article is distributed under the terms of the Creative Commons Attribution 4.0 International License (http://creativecommons.org/licenses/by/4.0/), which permits unrestricted use, distribution, and reproduction in any medium, provided you give appropriate credit to the original author(s) and the source, provide a link to the Creative Commons license, and indicate if changes were made. The Creative Commons Public Domain Dedication waiver (http://creativecommons.org/ publicdomain/zero/1.0/) applies to the data made available in this article, unless otherwise stated. of phytase is also well recognized [8-10]. Literature studies over the past two decades have substantiated the advantages of phytase and have rapidly become a nutritional strategy to compact with the environmental and economic pressure.

Although the benefits of phytase to improve $\mathrm{P}$ and $\mathrm{Ca}$ digestibility are universally accepted and have been validated with several publications, their ratios in the feed formulation are not exploited much. Broiler diets are typically formulated for $10 \mathrm{~g}$ of $\mathrm{Ca} / \mathrm{kg}$ diet [11]. Ca has a lower affinity with phytate unlike other minerals; however, its higher concentration (higher than $1 \%$ in diet) plays the decisive role in determining the phytate-mineral complex [12]. The studies of Tamim and Angel [13] have reported on the negative effects of high $\mathrm{Ca}$ in phytase-mediated phytate hydrolysis in broilers. Increased dietary $\mathrm{Ca}$ hinders the action of phytase by forming insoluble Ca-phytate complexes in the digestive tract [14]. It also results in $\mathrm{Ca}$ competing for the active sites of phytase leading to a direct reduction of phytase activity. Reducing the ratio of dietary $\mathrm{Ca}$ to available $\mathrm{P}$ positively affects the $\mathrm{P}$ digestibility [15]. Contrary to the above finding, increasing the Ca level from 6.7 to 
$13.3 \mathrm{~g} / \mathrm{kg}$ did not affect phytase activity [16]. Delezie et al. [17] observed that reducing $\mathrm{Ca}$ and $\mathrm{P}$ concentrations by $20 \%$ with phytase supplementation could enhance broiler performance. Rama Rao et al. [18] stated that the $\mathrm{Ca}$ and $\mathrm{P}$ coexist in many biological functions though the dietary requirements are interdependent. Surplus calcium in the diet has been shown to increase the $\mathrm{pH}$ of the gizzard, digesta, and reduced phosphorous absorption by forming insoluble complexes in the intestinal lumen [19]. Lower calcium levels travail bone mineralization, causing excess phosphorous wastage through droppings. Hence, $\mathrm{Ca}: \mathrm{P}$ ratio in the diet is essential for the better utilization of both $\mathrm{Ca}$ and $\mathrm{P}$.

Several studies have confirmed the deleterious effect of excess $\mathrm{Ca}$ on phytase activity; however, there is a need to explore and define appropriate dietary non-phytate P (NPP) and Ca levels in poultry diet supplemented with phytase. Thus, the present study was conducted to understand the growth performance, mineral retention, and bone traits of broiler chicken at low $\mathrm{P}$ and $\mathrm{Ca}$ supplemented with laboratory produced fungal phytase by Aspergillus foetidus by immobilization technique. A. feotidus was employed for continuous, economic phytase production with improved stability and longer shelf life.

\section{Materials and Methods}

\section{Ethical approval}

All the experimental procedures and animal trial were executed with the approval of Ethical Committee of ICAR-National Institute of Animal Nutrition and Physiology, Bengaluru (Animal care and use protocol (No. 5/2012)).

\section{Phytase production}

A. foetidus MTCC 11682 was used for phytase production employing immobilization technique of adsorption. A thoroughly homogenized spore suspension of $5 \% \mathrm{w} / \mathrm{v}$ inoculum, extracted in $0.1 \%$ tween 20 , and physiological saline in the ratio of 1:5 were immobilized on polyurethane foam matrix. A scale-up phytase production was executed in an optimized media following the techniques of Lalpanmawia et al. [20]. The crude phytase obtained in repeated batch fermentation was filtered, centrifuged $(10,000 \mathrm{rpm}$ for $15 \mathrm{~min}$ ), and precipitated using $90 \%$ ammonium sulfate. The precipitates were liquefied in $0.2 \mathrm{M}$ sodium citrate buffer, $\mathrm{pH}$ 5.5. They were further concentrated and aliquoted to screw cap tubes in such a way that each tube had an activity of 500 FTU. The aliquots were stored at $-20^{\circ} \mathrm{C}$ for feeding trails. After thawing, the concentrated phytase of 500 FTU was added to $1 \mathrm{~kg}$ feed and mixed well.

\section{Birds and housing}

A 90 one-day-old, unsexed (maybe 50:50), Cobb 500 chicks were distributed into three treatment groups with five replicates under each treatment with six birds in each replicate in a completely randomized design
(30 birds per treatment). The chicks were housed in battery cages $(72 \mathrm{~cm}$ wide $\times 48 \mathrm{~cm}$ long $\times 38 \mathrm{~cm}$ high) as groups in a random manner allotted tiers from 0 to 4 weeks of age. Each battery cage was equipped with heating arrangements, feeders, drinkers, and dropping trays. The cages were placed in a well-ventilated opensided house with $24 \mathrm{~h}$ lighting. Temperature inside the cage was maintained at $33^{\circ} \mathrm{C}$ at the start and was gradually reduced to $25^{\circ} \mathrm{C}$. The room temperature was around $24-25^{\circ} \mathrm{C}$ with a relative humidity of $50-60 \%$. Feed and fresh water was provided ad libitum. The experiment was conducted for 28 days.

\section{Experimental design}

Treatment 1 (T1) consisted of standard available phosphorus (AP) with $0.45 \%$ NPP during starter (0-21 days) and $0.40 \%$ during the finisher (21-28 days) phase along with $1 \% \mathrm{Ca}$ throughout the growing phase. Treatment 2 (T2) was with low phosphorus $(0.37 \%$ during starter and $0.32 \%$ in finisher phase) with phytase at $500 \mathrm{FTU} / \mathrm{kg}$ diet and $1 \% \mathrm{Ca}$. Treatment 3 (T3) was a low phosphorus $(0.37 \%$ during starter and $0.32 \%$ in finisher phase) and low calcium of $0.8 \%$ with phytase at $500 \mathrm{FTU} / \mathrm{kg}$ diet. The details of the ingredient and nutrient composition are briefed in Table-1.

\section{Growth performance}

Body weight (BW) and feed intake (FI) were recorded on weekly basis to calculate feed conversion ratio (FCR) on the basis of unit feed consumed to unit BW gain (BWG).

\section{Metabolic trial}

A 3-day metabolic trial was conducted on day 23. Measured amount of feed was offered, and daily feed consumption and residual feed were recorded on cage basis. Excreta voided were collected at the end of metabolic trial from each replicate, homogenized thoroughly, and weighed. Representative samples of the excreta were dried in an oven at $60^{\circ} \mathrm{C}$, grounded uniformly, and ashed in muffle furnace at $600^{\circ} \mathrm{C}$. The ashed samples were digested with dilute hydrochloric acid $(\mathrm{HCl})$, and the extract was used for mineral estimation using inductively coupled plasma optical emission spectroscopy (ICP-OES), a PerkinElmer instrument, Waltham, Massachusetts, US. All calculations were expressed on dry matter (DM) basis. The difference in the nutrient content of the feed consumed and of the droppings was used to calculate the retention of nutrients $(\mathrm{Ca}$ and $\mathrm{P})$ on percentage $\mathrm{DM}$ basis.

\section{Carcass quality}

At the end of the experiment, 10 birds per treatment ( 2 birds per group) were sacrificed randomly by cervical dislocation. The carcass weight and weight of liver, gizzard, and heart were recorded.

\section{Bone morphometry and mineral estimation}

The left tibia was collected from the sacrificed birds. The adhering tissues were cleaned and dried. Total length and proximal and distal epiphysis and diaphysis width were measured using a digital 
Vernier caliper. Tibia was defatted in petroleum ether (boiling point $60-80^{\circ} \mathrm{C}$ ) using Soxhlet apparatus, dried to a constant weight in a drying oven, and ashed for $12 \mathrm{~h}$ at $600^{\circ} \mathrm{C}$. The ashed samples were digested with dilute $\mathrm{HCl}$, and the mineral extract prepared was used for the estimation of $\mathrm{Ca}, \mathrm{P}, \mathrm{Mn}$, and zinc $(\mathrm{Zn})$ using ICP-OES.

\section{Phytate and phytase estimation}

Phytate P content of feed was estimated as described by Haugh and Lantzsch [21]. Phytase estimation was as per Kim and Lei [22].

\section{Statistical analysis}

The experimental data were subjected to one-way analysis of variance for fully randomized design and tested for significance among the three treatments using Turkey's ASD post hoc test (SPSS-2010 version 18.0).

\section{Results}

\section{Growth performance}

BWG, FI, and FCR did not differ significantly ( $p>0.05$ ) among the three treatment groups during the entire phase (Table-2). Carcass traits (eviscerated and giblet weight) were not influenced ( $\mathrm{p}>0.05)$ by dietary $\mathrm{AP}$ and/or phytase supplementation (Table-3).

Table-1: Ingredient and nutrient composition of experimental diets during starter (0-3 weeks) phase and finisher phase (3-4 weeks).

\begin{tabular}{|c|c|c|c|c|c|c|}
\hline \multirow[t]{2}{*}{ Ingredients } & \multicolumn{3}{|c|}{ Starter (0-3 weeks) } & \multicolumn{3}{|c|}{ Finisher (3-4 weeks) } \\
\hline & T1 & T2 & T3 & T1 & $\mathbf{T 2}$ & T3 \\
\hline \multicolumn{7}{|c|}{ Ingredient composition as fed basis (\%) } \\
\hline Maize & 56.97 & 57.12 & 57.62 & 63.40 & 63.60 & 64.15 \\
\hline Soybean meal & 37 & 37 & 37 & 31 & 31 & 31 \\
\hline Sunflower oil & 2.2 & 2.2 & 2.2 & 2 & 2 & 2 \\
\hline Lime stone & 1 & 1.3 & 0.8 & 1.2 & 1.5 & 0.95 \\
\hline $\mathrm{DCP}$ & 1.75 & 1.3 & 1.3 & 1.5 & 1 & 1 \\
\hline Salt & 0.35 & 0.35 & 0.35 & 0.35 & 0.35 & 0.35 \\
\hline Lysine & 0.3 & 0.3 & 0.3 & 0.2 & 0.2 & 0.2 \\
\hline Methionine & 0.18 & 0.18 & 0.18 & 0.1 & 0.1 & 0.1 \\
\hline $\begin{array}{l}\text { Vitamin } \\
\text { premix* }\end{array}$ & 0.25 & 0.25 & 0.25 & 0.25 & 0.25 & 0.25 \\
\hline Phytase (FTU) & 0.0 & 500 & 500 & 0.0 & 500 & 500 \\
\hline \multicolumn{7}{|c|}{ Nutrient composition $(\mathrm{g} / \mathrm{kg})$} \\
\hline $\mathrm{ME}, \mathrm{kcal} / \mathrm{kg}$ & 2996 & 2996 & 3012 & 3050 & 3055 & 3071 \\
\hline $\mathrm{CP}$ & 22.3 & 22.3 & 22.4 & 20.09 & 20.10 & 20.15 \\
\hline Lysine & 1.44 & 1.44 & 1.44 & 1.15 & 1.15 & 1.15 \\
\hline Methionine & 0.49 & 0.49 & 0.49 & 0.46 & 0.46 & 0.46 \\
\hline $\mathrm{Ca}$ & 1.00 & 1.01 & 0.82 & 1.01 & 1.01 & 0.80 \\
\hline P, avail. & 0.45 & 0.37 & 0.37 & 0.40 & 0.32 & 0.32 \\
\hline
\end{tabular}

*Trace mineral premix, $1 \mathrm{~g} / \mathrm{kg}$; Vitamin premix, $1 \mathrm{~g} / \mathrm{kg}$; and Choline $0.5 \mathrm{~g} / \mathrm{kg}$. Trace mineral premix supplied $\mathrm{mg} / \mathrm{kg}$ diet: $\mathrm{Mg}, 300 ; \mathrm{Mn}, 55 ; \mathrm{I}, 0.4 ; \mathrm{Fe}, 56 ; \mathrm{Zn}, 30$; and $\mathrm{Cu}$, 4. The vitamin premix supplied per kg diet: Vitamin A, 8250 IU; Vitamin D3, 1200 ICU; Vitamin K, 1 mg; Vitamin E, 40 IU; Vitamin B1, 2 mg; Vitamin B2, 4 mg; Vitamin B12, 10 mg; niacin, $60 \mathrm{mg}$; pantothenic acid, $10 \mathrm{mg}$; and choline, $500 \mathrm{mg}$

Table-2: Growth performance of broiler chicken.

\begin{tabular}{|c|c|c|c|c|c|c|}
\hline \multirow[t]{2}{*}{ Groups } & \multicolumn{2}{|c|}{ BWG (g/b) } & \multicolumn{2}{|c|}{ FI $(g / b)$} & \multicolumn{2}{|c|}{ FCR } \\
\hline & 0-3 weeks & 0-4 weeks & 0-3 weeks & 0-4 weeks & 0-3 weeks & 0-4 weeks \\
\hline $\mathrm{T} 1$ & 814 & 1346 & 1129 & 1843 & 1.32 & 1.37 \\
\hline $\mathrm{T} 2$ & 841 & 1349 & 1134 & 1876 & 1.28 & 1.39 \\
\hline T3 & 809 & 1293 & 1111 & 1834 & 1.31 & 1.42 \\
\hline SEM & 13.42 & 14.28 & 7.68 & 13.82 & 0.023 & 0.016 \\
\hline Significance & 0.62 & 0.21 & 0.45 & 0.45 & 0.82 & 0.53 \\
\hline
\end{tabular}

SEM =Standard error of mean, T1=Control group, T2=Low $P+500$ FTU lab phytase, T3=Low P, low Ca+500 FTU lab phytase. $\mathrm{BWG}=$ Body weight gain, $\mathrm{FI}=$ Feed intake, $\mathrm{FCR}=$ Feed conversion ratio

Table-3: Influence of dietary treatment on the carcass traits of broilers.

\begin{tabular}{lccccc}
\hline Carcass Traits (\% of live weight) & T1 & T2 & T3 & SEM & Significance \\
\hline Eviscerated & 60.06 & 60.17 & 59.99 & 0.34 & 0.98 \\
Liver & 2.30 & 2.33 & 2.21 & 0.04 & 0.43 \\
Gizzard & 2.24 & 2.19 & 2.38 & 0.06 & 0.43 \\
Heart & 0.62 & 0.67 & 0.64 & 0.013 & 0.21 \\
Giblet & 5.16 & 5.19 & 5.23 & 0.073 & 0.94 \\
\hline
\end{tabular}

SEM=standard error of mean, T1=Control group, T2=Low $P+500$ FTU lab phytase, T3=Low P, low Ca+500 FTU lab phytase 


\section{Mineral and DM retention}

Phytase supplementation did not show any significant improvement ( $\mathrm{p}>0.05)$ in $\mathrm{DM}$ and calcium retention (Table-4). A significantly $(\mathrm{p}<0.05)$ higher retention of $\mathrm{P}$ by birds was observed in T2 (low AP level with phytase supplementation at $500 \mathrm{FTU} / \mathrm{kg}$ ) and T3 (lower P and Ca with phytase at $500 \mathrm{FTU} / \mathrm{kg}$ ).

\section{Bone morphometry and mineralization}

The bone weight, bone length, and bone width were similar $(p>0.05)$ among the treatment groups (Table-5). Dry weight of tibia did not show any significant difference $(p>0.05)$ among treatments. The tibia bone had similar $(p>0.05)$ ash contents among the three dietary treatments of birds, and the same trend was also observed for $\mathrm{Ca}, \mathrm{P}$, and $\mathrm{Mn}$ content of the ash (Table-6). Supplementation of phytase at 500 FTU/kg did not increase the $\mathrm{Zn}$ content in T2 and T3. On the contrary, the control treatment showed an increased concentration of $\mathrm{Zn}$ in bone ash $(\mathrm{p}<0.05)$.

\section{Discussion}

Phytase supplementation in low-P diet (0.30-0.38 AP in diet) increases growth performance in broiler chicken [23]. Limited studies are available on broiler trials performed with laboratory produced phytase [20,24-26]. Ahmad et al. [24] observed

Table-4: Influence of dietary treatments on the retention (\%) of dietary minerals.

\begin{tabular}{lccccc}
\hline Retention (\%) & \multicolumn{3}{c}{ Groups } & SEM & Significance \\
\cline { 2 - 4 } & T1 & T2 & T3 & & \\
\hline DM & 62.6 & 62.0 & 59.4 & 0.012 & 0.46 \\
Ca & 36.5 & 39.8 & 39.9 & 0.017 & 0.68 \\
P & $42.2^{\text {b }}$ & $49.3^{\text {a }}$ & $51.1^{\text {a }}$ & 0.015 & 0.02 \\
\hline
\end{tabular}

a,bMeans with different superscripts in a row differ significantly $(p<0.05)$. SEM=Standard error of mean, T1=Control group, T2=Low $P+500$ FTU lab phytase, $\mathrm{T} 3=$ Low $\mathrm{P}$, low Ca+500 FTU lab phytase. DM=Dry matter comparable results between phytases produced from Aspergillus niger, supplemented at $500 \mathrm{FTU} / \mathrm{kg}$ diet and normal $\mathrm{P}$ diet group in his 28-day trial. They reported a BWG of 869 versus $856 \mathrm{~g} /$ bird, FI of 1187 versus $1137 \mathrm{~g} / \mathrm{bird}$, and FCR of 1.36 versus 1.33 . In the comparative study of Lan et al. [25] between birds fed on low AP diet supplemented with freeze-dried active Mitsuokella jalaludini culture, a rumen bacteria and natuphos phytase both equivalent to $500 \mathrm{FTU} /$ $\mathrm{kg}$ diet observed similar BWG (784 vs. $797 \mathrm{~g} / \mathrm{bird}$ ), lower FI (1015 vs. 1058), and significantly better FCR (1.38 vs. 1.41). However, the studies of Lalpanmawia et al. [20] reported a lower growth rate (1598 vs. $1744 \mathrm{~g} /$ bird), a lower FI (2576 vs. 2808), and a similar FCR (1.61 vs. 1.63) in broiler fed with low AP complementing with $500 \mathrm{FTU} / \mathrm{kg}$ laboratory produced phytase compared to normal P-fed group. Although the findings of Manobhavan et al. [26] highlight on the benefits of phytase superdosing up to $5000 \mathrm{FTU} /$ $\mathrm{kg}$ over the standard $500 \mathrm{FTU} / \mathrm{kg}$ diet, similar BWG (1642 vs. 1669), FI (2634 vs. 2697), and FCR (1.61 vs. 1.62) were reported for broilers fed on low AP diet with lab phytase supplemented at $500 \mathrm{FTU} / \mathrm{kg}$ in comparison with chickens fed on normal $\mathrm{P}$. The current study is in agreement with the results of the previous findings, exhibiting in par performance of normal $\mathrm{P}$ to low $\mathrm{P}$ group supplemented with phytase at $500 \mathrm{FTU} / \mathrm{kg}$. The comparable growth performance observed in all the three dietary treatments might be due to the release and utilization of $\mathrm{P}$ from the phytate mineral complex [27]. A better FCR (1.96 vs. 2.08) was observed with phytase supplementation at 500 FTU when compared to non-supplemented group [28]. Similarly, Akter et al. [29] reported on a better FCR in birds supplemented with phytase and medium Ca diet. However, Rutherfurd et al. [30] studied that there was no effect on the FI:BWG for the birds fed on low P diet supplemented phytase at 1000 and 2000

Table-5: Bone morphometry (left tibia) of broiler chicken on different dietary treatment.

\begin{tabular}{|c|c|c|c|c|c|}
\hline \multirow[t]{2}{*}{ Treatment } & \multirow{2}{*}{$\begin{array}{c}\text { Bone weight } \\
\text { (g/kg live weight) }\end{array}$} & \multirow{2}{*}{$\begin{array}{c}\text { Bone length } \\
(\mathrm{mm} / \mathrm{kg} \text { live weight) }\end{array}$} & \multicolumn{3}{|c|}{ Bone width (mm/kg live weight) } \\
\hline & & & Proximal epiphysis & Diaphysis & Distal epiphysis \\
\hline $\mathrm{T} 1$ & 2.78 & 55.73 & 13.14 & 5.12 & 10.36 \\
\hline T2 & 2.69 & 54.59 & 13.56 & 5.16 & 11.13 \\
\hline T3 & 2.58 & 54.12 & 13.29 & 5.42 & 10.61 \\
\hline SEM & 0.04 & 0.82 & 0.17 & 0.09 & 0.19 \\
\hline Significance & 0.17 & 0.73 & 0.62 & 0.35 & 0.27 \\
\hline
\end{tabular}

SEM $=$ Standard error of mean, T1=Control group, $T 2=$ Low $P+500$ FTU lab phytase and T3=Low $\mathrm{P}$, low Ca+500 FTU lab phytase

Table-6: The effect of dietary treatments on bone mineralization.

\begin{tabular}{lccccc}
\hline Treatment & Ash (\%) & Calcium (\%) & Phosphorus (\%) & Zinc (ppm) & Manganese (ppm) \\
\hline T1 & 41.8 & 19.45 & 10.39 & $229.4^{\mathrm{b}}$ & 138.7 \\
T2 & 40.7 & 18.04 & 9.88 & $162.2^{\mathrm{a}}$ & 136.4 \\
T3 & 39.7 & 18.72 & 10.17 & $165.0^{\mathrm{a}}$ & 141.8 \\
SEM & 0.01 & 0.47 & 0.25 & 11.34 & 3.16 \\
Significance & 0.36 & 0.49 & 0.72 & 0.02 & 0.79
\end{tabular}

$a, b$ Means with different superscripts in a row differ significantly $(p<0.05)$. SEM=Standard error of mean, T1=Control group, T2=Low $P+500$ FTU lab phytase, T3=Low $\mathrm{P}$, low Ca+500 FTU lab phytase 
FTU/kg compared with non-supplemented low P diet, and performance was equal to that of the normal AP diet. Supplemental phytase aids in releasing bound organic nutrients and removing the negative effects of phytic acid on proteolytic enzymes leading to increased DM digestibility [7]. The higher P retention observed in the phytase supplemented group can be credited to the increased P bioavailability [31] and the homeostasis mechanism exhibited by broiler that increases retention and absorption of $\mathrm{P}$ at low dietary intake when compared to normal dietary P. Sebastian et al. [27] observed an increase in $\mathrm{Ca}$ and $\mathrm{P}$ retention in chicken by 12.4 and $12.2 \%$, respectively, when fed with corn soya-based diet (low P level $0.5 \%$ ) supplemented with phytase at $600 \mathrm{FTU} / \mathrm{kg}$.

Chung et al. [32] reported that phytase supplementation had no significant impact on tibial ash from broiler, which is in complete agreement with the current study. Various studies have substantiated the improved bone mineral content, bone density, and bone breaking strength with phytase supplementation [27,33]. Phytase resulted in better mineralization of bone by improving the availability of $\mathrm{Ca}$ and P. Kiarie et al. [34] reported on the role of phytase in improved digestibility of minerals such as $\mathrm{Ca}$ and $\mathrm{Mg}$ other than P, due to decreased phytate-Ca complex formation in the gastrointestinal tract of poultry. The comparable results for $\mathrm{Ca}-\mathrm{P}$ retention obtained in phytase supplemental group to that of standard AP indicate phytate $\mathrm{P}$ utilization by microbial phytase and the release of $\mathrm{Ca}$ from Ca-phytate complex. Phytase along with inorganic $\mathrm{P}$ intensifies bone length, tibia ash, tibial strength, and mineralization of cartilage and bone cells [35]. In an experiment with 30-day-old broilers fed on corn-soybean diet, a reduction in tibiotarsus ash content was found when the Ca and NPP levels of the diets decreased from $10-4.5$ to $7.5-3 \mathrm{~g} / \mathrm{kg}$ and the content was not affected by phytase supplementation [36]. The beneficial effects of phytase might be attributed to the release of minerals from complexes with phytic acid and promoting the deposition of minerals in bone [23]. The increase in $\mathrm{Zn}$ concentration in bone ash exhibited by control group could be due to some antagonistic effect; however, the exact reason is not known.

There is a need to demarcate the proportionate $\mathrm{Ca}$ level and $\mathrm{Ca}$ : $\mathrm{P}$ ratio in phytase supplemented diets for broilers [12]. The studies of Qian et al. [37] recommend Ca: P ratio in the range of 1.1-1.4: 1 for broilers. The report also says that higher levels of $\mathrm{Ca}$ (5.61$10.20 \mathrm{~g} / \mathrm{kg}$ ) and Ca: P ratio of 1.1-2.0:1 had a negative impact on the weight gain $(420 \mathrm{~g} /$ bird vs. $553 \mathrm{~g} / \mathrm{bird})$ of 21-day-old broiler. However, phytase supplementation at $900 \mathrm{FTU} / \mathrm{kg}$ boosted the weight gain in broilers fed on higher $(541 \mathrm{~g} / \mathrm{bird}$ vs. $420 \mathrm{~g} / \mathrm{bird})$ and lower (615 g/bird vs. 553 g/bird) Ca: P ratio [37]. Applegate et al. [38] reported that conventionally used dietary $\mathrm{Ca}$ levels in broiler diets $(0.9 \%)$ resulted in the reduction of intestinal phytase activity and in apparent ileal PP hydrolysis compared with a lower level of $\mathrm{Ca}(0.4 \%)$. Increasing $\mathrm{Ca}$ concentration in phytase-supplemented diets caused a linear decrease in the BWG, FI, and feed efficiency in broiler chicken [39]. Tamim et al. [40] reported that limited dietary $\mathrm{Ca}$ could initiate endogenous phytases to hydrolyze $80 \%$ phytate in excess. This was substantiated by the studies of Wilkinson et al. [41], who reported on the synchronized assimilation of Ca-phytate and phytate hydrolysis by endogenous phytase attained by spatial separation of $\mathrm{Ca}$ from the grain portion of the diet. Li et al. [42] supported the proposal that low $\mathrm{P}$ levels upregulate mucosal phytase activity which should be facilitated by low $\mathrm{Ca}$ levels. Zeller et al. [43] reported on the level of intestinal IP6 desertion and iP addition. They observed a hydrolysis of IP6 by $67 \%$ in the jejunum and $78 \%$ in the ileum in a corn-soybean diet without monocalcium phosphate and supplemented Escherichia coli phytase at $500 \mathrm{FTU} / \mathrm{kg}$ diet. Dietary Ca level between 5 and $7 \mathrm{~g} / \mathrm{kg}$ would be insufficient for bone mineralization irrespective of phytase supplementation [44]. The present study observed lowering of $\mathrm{Ca}$ level up to $0.8 \%$ in starter and finisher diets with low NPP and supplemented phytase at $500 \mathrm{FTU} / \mathrm{kg}$ diet. However, dietary $\mathrm{Ca}$ reduction should be proportional to total $\mathrm{P}$ reduction maintaining Ca:P ratio as observed by Qian et al. [37].

\section{Conclusion}

The study indicated that $500 \mathrm{FTU} / \mathrm{kg}$ phytase can be effectively supplemented in a broiler diet with low phosphorus $(0.37 \%$ in starter and $0.32 \%$ NPP in finisher diet) and low calcium ( $0.8 \%$ in diet) successfully replacing $0.08 \%$ of dietary $\mathrm{P}$ and reduced $\mathrm{P}$ excretion into the environment.

\section{Authors' Contributions}

AVE designed and supervised the experiment. SA executed the experiments and wrote the manuscript. DS and VBA helped in conducting the experiments. KB and DP helped in the ICP work. JG and AVE corrected the manuscript. All authors have read and approved the manuscript.

\section{Acknowledgments}

The financial support received from Department of Biotechnology (S.R.C.No_Bt/PR3178/AAQ/ 01/476/01/476/2011), Government of India is thankfully acknowledged.

\section{Competing Interests}

The authors declare that they have no competing interests.

\section{References}

1. Dersjant, L.Y., Awati, A., Schulze, H. and Partridge, G. (2014) Phytase non ruminant animal nutrition: A critical review on phytase activities in the gastrointestinal tract and influencing factors. J. Sci. Food Agric., 95: 878-896. 
2. Ravindran, V., Cabahug, S., Ravindran, G. and Bryden, W.L. (1999) Influence of microbial phytase on apparent ileal amino acid digestibility in feedstuffs for broilers. Poult. Sci., 78: 699-706.

3. Murai, A., Kobayashi, T., Okada, T. and Okamura, J. (2002) Improvement of growth and nutritive value in chicks with non-genetically modified phytase product from Aspergillus niger. Br. Poult. Sci., 43: 687-695.

4. Cowieson, A.J. and Adeola, O. (2005) Carbohydrases, proteases and phytase have an additive beneficial effect in nutritionally marginal diets for broiler chickens. Poult. Sci., 84: 1860-1867.

5. Butani, J.B. and Parnerkar, S. (2015) Role of microbial phytase in broiler nutrition-a review. J. Livest. Sci., 6: 113-118.

6. Rashti, M.G., Shariatmadari, F., Torshizi, M.A.K. and Asli, M.M. (2016) Effects of dietary propionic acid, sodium citrate, and phytase on growth performance, mineral digestibility, and tibia properties in broilers. J. Appl. Anim. Res., 44(1): 370-375.

7. Ravindran, V., Morel, P.C.H., Partridge, G.G., Hruby, M. and Sands, J.S. (2006) Influence of an E. coli-derived phytase on nutrient utilization in broilers fed starter diets containing varying concentrations of phytic acid. Poult. Sci., 85:82-89.

8. Selle, P.H., Ravindran, V. and Partridge, G.G. (2009) Beneficial effects of xylanase and/or phytase inclusions on ileal amino acid digestibility, energy utilisation, mineral retention and growth performance in wheat-based broiler diets. Anim. Feed Sci. Technol., 53: 303-313.

9. Simons, P.C.M., Versteegh, H.A.J., Jongbloed, A.W., Kemme, P.A., Slump, P., Bos, K.D., Wolters, M.G.E., Beudeker, R.F. and Verschooor, G.J. (1990) Improvement of phosphorus availability by microbial phytase in broilers and pigs. Br. J. Nutr., 64: 525-540.

10. Schlegel, P., Sauvant, D. and Jondreville, C. (2013) Bioavailability of $\mathrm{Zn}$ sources and their interaction with phytases in broilers and piglets. Animal, 7(1): 47-59.

11. NRC. (1994) Nutrient Requirements of Poultry. $9^{\text {th }}$ Rev. ed. The National Academies Press, Washington, DC.

12. Angel, R., Tamim, N.M., Applegate, T.J., Dhandu, A.S. and Ellestad, L.E. (2002) Phytic acid chemistry: Influence on phytin-phosphorus availability and phytase efficacy. $J$ Appl. Poult. Res., 11: 471-480.

13. Tamim, N.M. and Angel, R. (2003) Phytate phosphorus hydrolysis as influenced by dietary calcium and micro-mineral source in broiler diets. J. Agric. Food Chem., 51: 4687-4693.

14. Amerah, A.M., Plumstead, P.W., Barnard, L.P. and Kumar, A. (2014) Effect of calcium level and phytase addition on ileal phytate degradation and amino acid digestibility of broilers fed corn-based diets. Poult. Sci., 93: 906-915.

15. Zaefarian, F., Romero, J.F. and Ravindran, V. (2013) Influence of a microbial phytase on the performance and the utilization of energy, crude protein and fatty acids of young broilers fed on phosphorus-adequate maize-and wheat-based diets. Br. Poult. Sci., 54: 653-660.

16. Powell, S., Bidner, T.D. and Southern, L.L. (2011) Phytase supplementation improved growth performance and bone characteristics in broilers fed varying levels of dietary calcium. Poult. Sci., 90: 604-608.

17. Delezie, E., Bierman, K., Nollet, L. and Maertens, I. (2015) Impacts of calcium and phosphorus concentration, their ratio and phytase supplementation level on growth performance, footpad lesions and hock burn of broiler chickens. $J$. Appl. Poult. Res., 24: 115-126.

18. Rama Rao, S.V., Raju, M.V.L.N., Reddy, M.R. and Pavani, P. (2006) Interaction between dietary calcium and non-phytate phosphorus levels on growth, bone mineralization and mineral excretion in commercial broilers. Anim. Feed Sci. Technol., 131: 135-150.

19. Walk, C.L., Bedford, M.R. and Mcelroy, A.P. (2012) Influence of limestone and phytase on broiler performance, gastrointestinal $\mathrm{pH}$, and apparent ileal nutrient digestibility. Poult. Sci., 91: 1371-1378.

20. Lalpanmawia, H., Elangovan, A.V., Sridhar, M., Shet, D., Ajith, S. and Pal, D.T. (2014) Efficacy of phytase on growth performance, nutrient utilization and bone mineralization in broiler chicken. Anim. Feed Sci. Technol., 192: 81-89.

21. Haugh, W. and Lantzsch, H.J. (1983) Sensitive method for the rapid determination of phytate in cereals and cereal products. J. Sci. Food Agric., 34: 1423-26.

22. Kim, T.W. and Lei, X.G. (2005) An improved method for a rapid determination of phytase activity in animal feed. $J$. Anim. Sci., 83: 1062-1067.

23. Selle, P.H. and Ravindran, V. (2007) Microbial phytase in poultry nutrition. Anim. Feed Sci. Technol., 135: 1-41.

24. Ahmad, T., Rasool, S., Sarwar, M., Haq, A.V. and Hasan, Z.U. (2000) Effect of microbial phytase produced from a fungus Aspergillus niger on bioavailability of phosphorus and calcium in broiler chickens. Anim. Feed Sci. Technol., 83: 103-114.

25. Lan, G., Abdullah, N., Jalaludin, S. and Hoa, Y.W. (2012) Effects of freeze-dried Mitsuokella jalaludinii culture and natuphos phytase supplementation on the performance and nutrient utilization of broiler chickens. J. Sci. Food Agric., 92: 266-273.

26. Manobhavan, M., Elangovan, A.V., Sridhar, M., Shet, D., Ajith, S., Pal, D.T. and Gowda, N.K.S. (2015) Effect of super dosing of phytase on growth performance, ileal digestibility and bone characteristics in broilers fed cornsoya-based diets. J. Anim. Physiol. Anim. Nutr., 100(1): 93-100.

27. Sebastian, S., Touchburn, S.P., Chavez, E.R. and Lague, P.C. (1996) The effects of supplemental microbial phytase on the performance and utilization of dietary calcium, phosphorus, copper, and zinc in broiler chickens fed corn-soybean diets. Poult. Sci., 75: 729-36.

28. Beiki, M., Hashemi, S.M. and Yaghoobfar, A. (2013) The use of phytase and low phosphorus levels in broiler diets with different metabolizable energy levels. J. Anim. Poult. Sci., 2(2): 48-54.

29. Akter, M., Graham, H. and Iji, P.A. (2016) Response of broiler chickens to different levels of calcium, non phytate phosphorus and phytase. Br. Poult. Sci., 57: 799-809.

30. Rutherfurd, S.M., Chung, T.K., Thomas, D.V., Zou, M.L. and Moughan, P.J. (2012) Effect of a novel phytase on growth performance, apparent metabolizable energy and the availability of minerals and amino acid in a low phosphorus corn-soybean meal diet for broilers. Poult. Sci., 91: 1118-1127.

31. Liu, B., Rafiq, A., Tzeng, Y. and Rob, A. (1998) The induction and characterization of phytase and beyond. Enzym. Microb. Tech., 22: 415-424.

32. Chung, T.K., Rutherfurd, S.M., Thomas, D.V. and Moughan, P.J. (2013) Effect of two microbial phytases on mineral availability and retention and bone mineral density in low-phosphorus diets for broilers. Br. Poult. Sci., 54: 362-373.

33. Singh, A., Walk, C.L., Ghosh, T.K., Bedford, M.R. and Haldar, S. (2013) Effect of a novel microbial phytase on production performance and tibia mineral concentration in broiler chickens given low-calcium diets. Br. Poult. Sci., 54: 206-215.

34. Kiarie, E., Woyengo, T. and Nyachoti, C.M. (2015) Efficacy of new 6-phytase from Buttiauxella spp. on growth performance and nutrient retention in broiler chickens fed corn-soybean meal-based diets. Asian Australas. J. Anim. Sci., 28: 1479-1487.

35. Qian, H., Kornegay, E.T. and Denbow, D.M. (1996) Phosphorus equivalence of microbial phytase in turkey diets as influenced by calcium to phosphorus levels. Poult. Sci., 75: 69-81.

36. Rama Rao, S.V., Reddy, V.R. and Reddy, R.S. (1999) Enhancement of phytate phosphorus availability in the diets 
of commercial broilers and layers. Anim. Feed Sci. Technol., 79: 211-222

37. Qian, H., Kornegay, E.T. and Denbow, D.M. (1997) Utilization of phytate phosphorus and calcium as influenced by microbial phytase, cholecalciferol, and the calcium: Total phosphorus ratio in broiler diets. Poult. Sci., 76: 37-46.

38. Applegate, T.J., Angel, R. and Classen, H.L. (2003) Effect of dietary calcium, 25-hydroxycholecalciferol, or bird strain on small intestinal phytase activity in broiler chickens. Poult. Sci., 82: 1140-1148.

39. Kim, J.H., Han, G.P., Shin, J.E. and Kil, D.Y. (2017) Effect of dietary calcium concentration in phytase containing diets on growth performance, bone mineralization, litter quality and footpad dermatitis score in broiler chickens. Anim. Feed Sci. Technol., 229: 13-18.

40. Tamim, N.M., Angel, R. and Christman, M. (2004) Influence of dietary calcium and phytase on phytate phosphorus hydrolysis in broiler chicken. Poult. Sci., 83: 1358-1367.

41. Wilkinson, S.J., Selle, P.H., Bedford, M.R. and
Cowienson, A.J. (2014) Separate feeding of calcium improves performance and nutrient digestibility in broiler chicks. Anim. Prod. Sci., 54: 172-178.

42. Li, W., Angel, R., Kim, S.W., Brady, K., Yu, S. and Plumstead, P.W. (2016) Impacts of dietary calcium, phytate, and nonphytate phosphorus concentrations in the presence or absence of phytase on inositol hexakisphosphate (IP6) degradation in different segments of broilers digestive tract. Poult. Sci., 95: 581-589.

43. Zeller, E., Schollenberger, M., Witzig, M., Shastak, Y., Kuhn, I., Hoelzle, E. and Rodehutscord, M. (2015) Interaction between supplemented mineral phosphorous and phytase on phytate hydrolysis and inositol phosphates in the small intestine of broilers. Poult. Sci., 94: 1018-1029.

44. Yan, F., Kersey, J.H., Fritts, C.A. and Waldroup, P.W. (2006) Effects of phytase supplementation on the calcium requirement of broiler chickens. Int. J. Poult. Sci., 5: 112-120.

$* * * * * * * *$ 